\title{
Incorporating Learning Styles to Motivate High School Students in Reading
}

\begin{abstract}
:
In the high school where this research was done, the biggest problem for the students, when it comes to English tests, is the reading section. Because they do not like reading, their reading scores are low. Reflecting to this fact, the idea of learning styles was applied in the reading class to help the students like reading so that they understand the text better. This research used mainly the idea of Visual Auditory and Kinesthetic learning styles suggested by Neil Fleming in 1992. The research was done in a class of forty students with different levels of English proficiency. There were three sessions in which each session had different learning styles applied to the activities. The result of this research was as expected with some exceptions. Both the ones who have high and low level of English understand the reading texts better when the learning styles applied match with theirs. However, there were also special cases in which students got their highest scores in the sessions that did not match with their personal learning styles. One of the possibilities on why these special cases occurred is the possible existence of the secondary learning styles. Neil Fleming mentioned in one of his journals that it is possible for these learning styles to overlap - one person can have more than one learning style with one style as the dominant learning style
\end{abstract}

Keywords: learning styles, reading, VAK

\section{Introduction}

For years, English has been part of the Indonesian National Curriculum and reading English texts have also been a problem in high school for several reasons. First, the tests and the focus of teaching in the classroom are different. There are four basic skills in learning English: speaking, reading, listening, writing and of English grammar, but during their school time - primary to high school, students are mostly exposed to grammar while the Secondary and High School's National Exam focuses only on listening and reading. This causes problems for students when they are near the National Exam since they are not used to doing reading and listening tasks. In the school where the research was done, a TOEFL mock test is conducted at the end of every semester to see the progress of the students. Most of the students who took the test scored badly on the Reading section.

Second, students' motivation in reading is not high. Reading has become one of the English skills that students dislike the most. Many students choose to study English through other skills such as use of language (grammar) and listening rather than reading. In his article "Why Students Hate Reading-And Often Aren't Very Good At It", Terry Heick (2014) says that there are reasons for that (1) teachers tend to teach reading in the old-fashioned way; (2) teachers often 'force' the students to do something that they do not have enough knowledge on the matter; and (3) the existence of technology. The case with the students in this particular school where the research was conducted, their interest in reading is quite low especially when it comes to read English text. There are some students who like reading English novels, but their number is not as many as those who do not like reading.

In order to make the students like reading, the idea of learning styles is incorporated in the class. Applying the idea of learning style in teaching students is one of the recent issues in the field of education. Even though the first idea of learning styles in the classrooms was proposed in the 1980 s, the issue is still going around. There are pros and cons about applying learning styles in the classroom. However, many education experts says the other way round; Dr. Herbert Puchta (2004 now), for example, is a full time writer of course books and other ELT materials and a professional teacher trainer (Puchta, 2017) He has written a number of ELT course books under the Cambridge University Press. He believes that each individual has their own unique, especially in their 
preferences in gaining new knowledge. Therefore, he has been creating course books with various activities to accommodate the different learning styles.

Generally speaking, there are different theories about learning styles, but the most popular one is the VAK (Visual, Auditory, and Kinesthetic) theory proposed by Walter Burke Barbe in 1981. The VAK theory says that every individual has their own preference in learning something. Some learn best through what they see, some through what they hear, and some other learn best from what they experience. The Visual style means that the individual learns best from graphics, pictures, and other visual objects. The second style is auditory which mean the individual learns best from listening to lectures, presentations, discussions, music, and other materials that allow them to listen. The third style is the Kinesthetic which means the individual with this learning style learns best by doing something, creating something based on the materials. This theory was later on expanded by Neil Fleming in 1992, which is used in this research. Neil Fleming expanded the styles by adding one more style: Reading and writing. In this learning style the individual learns best from reading and writing the material he has just learnt. Fleming and Mills (1992) also mentioned that it is possible that these learning styles will overlap. There will be people who have more than one learning styles (mostly combination of two). This combination of two learning styles is called multimodal learning style. People can have multimodal learning style because people are multimodal beings even if the person appears to be using, most of the time, only one learning model (Fleming and Mills, 2009).

Supporting to what Fleming and Mills (1992) said about how one individual can have more than one learning styles, Andrew D. Cohen (2010) explained in one of his writings that there are reasons on why one individual can have more than one learning styles. There are aspects based on the person senses, cognitive styles and personality that influence his types of learning style. He mentions that there are three learning styles preferences: (1) sensory/perceptual style preferences that discuss about the ways of learning based on the human's sensory, (2) personality - related style preferences which include extroverted or introverted, reflective or impulsive, and open or closureoriented, and 3) cognitive style preferences, which cover (a) being more global or more particular/detail-oriented; (b) being a more of a synthesizer and/or being analytic; (c) being more deductive or more inductive; (4) field dependent / field independent (Cohen, 2010, p. 163). However, this research was focusing only on the three learning styles by Neil Fleming (1992): visual, auditory, and kinesthetic because the questionnaire used for this research could only give out the dominant learning styles.

The idea of learning style here is applied to a reading activity because one of the important skills in learning English is reading. According to Merriam-Webster's Dictionary and Thesaurus (2014), read means 'to understand language by interpreting written symbols for speech sounds'. It can be said that reading is an action to understand language by interpreting written symbols - in this case letters. Reading is one of the four language skills. It is a receptive skill which means it involves "responding to the text rather than producing it" (Spratt, Pulverness, \& Williams, 2012). Basically, there are three main theories of reading: (1) the traditional theory/bottom up processing: a reading process by learning parts of language (letters) in order to understand the whole text. Based on the theory of reading by Gough (1974), bottom up process means the students begin by transferring the letters into sounds, then piece the sounds together to form individual word, then piece the words together to understand the writer's message of the whole text (Reutzel and Cooterm 2013). (2) The cognitive theory/top-down processing: a reading process in which the readers use their background information to predict what the text is about. Instead of using the sounds to recognize the text, students are given the whole text for them to decipher unfamiliar words. The top-down reading process is said to be one of the most effective methods for second language learners to learn how to read a passage. (3) The metacognitive/schema theory: this reading theory/process involves many steps in order to help the students to build up their reading skills. Unlike the two previous processes, the metacognitive/schema process requires the teacher to plan a step by step lesson to guide the students to have a strategic way of thinking. Questioning, visualizing, and synthesizing information are all ways that readers can examine their thinking process.

A group called RAND, through Catherine E. Snow in their older (2002) report: "Reading for understanding: toward a research and development program in Reading comprehension", says that in the reading process, there are three elements: (1) the reader who is doing the understanding; (2) the text that is to be understood; and (3) the activity in which understanding the text is a part (Snow, 
2002). The three elements are wrapped or surrounded by a bigger dimension called the Sociocultural Context. According to the report written by RAND (2016), this sociocultural context shapes and is shaped by the readers and interacts with the text and activity. Although this research is not focusing on the reading comprehension activity, the relation between reader, text, and activity is still important and something that teachers should consider.

In short, the three elements (reader, text, and activity) are connected to each other. The text given to the students should be based on their capabilities. Before reading the text, the students should have enough knowledge to understand the text given. If the text is too hard or the students do not have enough knowledge to understand the text, the reading activity will be useless. Therefore, in order to bridge the gap between the students' knowledge and the level of the text given, there should be activities that are interesting enough for the students - paying attention to learning styles - to help them understand the text (Snow, 2010; p.15).

\section{Methods}

This study focused on two things: Learning styles and Reading. The students' personal learning styles were taken from the test result — which was developed based on Neil Fleming's VAK (visual, auditory, and kinesthetic) learning styles (1992) - done by the school's counselors; it is the school's policy that every new student are (tenth grade students) to be tested for their individual learning styles on their first semester in High School. The result of the students' personal learning styles showed only one or the dominant learning styles.

The respondents of the questionnaire are forty High School students with different levels of English knowledge. These forty students were not chosen randomly. They belong to the same class. There were twelve classes of grade ten in the school. A class from the seven available science classes was chosen. This particular class was chosen because first, the students were active; second, the gap between the diligent and the lazy ones when it comes to reading activities was quite big (only a small number of students get excited in reading); third, the location and the size of the class allowed the students to do the activities freer and more comfortably. These students did not like reading. Many of them, failed their reading tests on their first English test and mid-term English test of their first year in High School. Therefore, this class was the appropriate class in which learning styles are applied.

As for the materials, there were three reading materials chosen for the action research. The three of them have the same genre so that the students did not get confused. The genre that the students focused on was Folklore, taken from a book of Folklore compilation from around the world called Readings for Peace Education through Folklore (2012). The stories were chosen from the book because the length of the stories was still manageable for the students and the stories were very interesting which is in line with Catherine E. Snow (2016) who said that the text should be suitable with the students' level of English. It was shown that during the auditory learning session, all of the students whose personal learning style is auditory did not have any problem with the text.

There were three different reading sessions during the action research. Different types of learning styles were applied to each reading text with the expectation that students comprehend the text better when the learning styles applied in each of the sessions match theirs. Each reading text and its activities were done at the same time by the whole class regardless their individual learning styles. There are two activities that are the same for all three reading session: (1) responding to the reading and (2) delving more deeply writing. The questions for the two sections are as shown in Table 1:

Table 1. Questions for the reading

\begin{tabular}{|l|l|l|l|}
\hline & \multicolumn{1}{|c|}{ Visual } & \multicolumn{1}{c|}{ Auditory } & \multicolumn{1}{c|}{ Kinesthetic } \\
\hline Responding to the & $\begin{array}{l}\text { 1. Did you like this } \\
\text { reading }\end{array}$ & $\begin{array}{l}\text { 1. Did you like this } \\
\text { story? Why or why } \\
\text { story? Why or why } \\
\text { not? }\end{array}$ & $\begin{array}{l}\text { 1. Did you like this } \\
\text { story? Why or why } \\
\text { not? }\end{array}$ \\
\cline { 2 - 4 } & $\begin{array}{l}\text { 2. The cat was } \\
\text { cheated so it lost }\end{array}$ & $\begin{array}{l}\text { 2. People say that in } \\
\text { relationship there }\end{array}$ & $\begin{array}{l}\text { 2. What is the best } \\
\text { way to overcome }\end{array}$ \\
\hline
\end{tabular}




\begin{tabular}{|c|c|c|c|}
\hline & $\begin{array}{l}\text { the contest. In a } \\
\text { competition do you } \\
\text { need to trick others } \\
\text { in order to win? }\end{array}$ & $\begin{array}{l}\text { should be mutual } \\
\text { understanding. How } \\
\text { do you implement } \\
\text { this value with your } \\
\text { friends and even } \\
\text { your enemies? }\end{array}$ & $\begin{array}{l}\text { injustice? How } \\
\text { could we follow } \\
\text { the little girl's } \\
\text { examples or do we } \\
\text { have other better } \\
\text { ways to overcome } \\
\text { it? }\end{array}$ \\
\hline $\begin{array}{l}\text { Delving more } \\
\text { deeply }\end{array}$ & $\begin{array}{l}\text { 1. The cat lazily } \\
\text { yawned and said, } \\
\text { "As soon as we } \\
\text { cross the river we } \\
\text { will be almost at } \\
\text { the finish line. } \\
\text { (par. } 7 \text { ). Why was } \\
\text { the cat so sure that } \\
\text { he would finish the } \\
\text { line first? }\end{array}$ & $\begin{array}{l}\text { 1. He knew not only } \\
\text { that the request was } \\
\text { impossible but that } \\
\text { he must obey or lose } \\
\text { his head and the } \\
\text { heads of all his } \\
\text { family. (par. 3). If } \\
\text { you were asked to } \\
\text { do something } \\
\text { impossible and that } \\
\text { threatened your life, } \\
\text { what would you do? } \\
\text { Do you think the } \\
\text { king doesn't have an } \\
\text { empathy to } \\
\text { Walukaga? }\end{array}$ & $\begin{array}{l}\text { 1. To settles their } \\
\text { quarrel they went } \\
\text { to the authorities. } \\
\text { (par.5). If you have } \\
\text { problems or } \\
\text { conflict, who do } \\
\text { you wish to be able } \\
\text { to solve your } \\
\text { problems or } \\
\text { conflict? Why do } \\
\text { you choose the } \\
\text { person? }\end{array}$ \\
\hline $\begin{array}{l}\text { Delving more } \\
\text { deeply (contd.) }\end{array}$ & $\begin{array}{l}\text { 2. To this day the } \\
\text { cat and the rat } \\
\text { remain mortal } \\
\text { enemies, and the } \\
\text { rat, ashamed of } \\
\text { the way he won } \\
\text { first place in the } \\
\text { zodiac, hides all } \\
\text { day in dark } \\
\text { corners and will } \\
\text { only come out at } \\
\text { night. (par } 21 \text { ) } \\
\text { Why should the rat } \\
\text { feel ashamed? } \\
\text { What kind of } \\
\text { victory would you } \\
\text { be proud of? }\end{array}$ & $\begin{array}{l}\text { 2. Walukaga knew } \\
\text { immediately that the } \\
\text { madman's advice } \\
\text { alone could cure the } \\
\text { king's madness and } \\
\text { save his family. } \\
\text { (par. 5). How did } \\
\text { Walukaga know that } \\
\text { the mad man can } \\
\text { solve his problem? } \\
\text { Was the mad man } \\
\text { more able to } \\
\text { empathize than the } \\
\text { king? }\end{array}$ & $\begin{array}{l}\text { 2. I want her to } \\
\text { come neither on } \\
\text { foot nor on } \\
\text { horseback, neither } \\
\text { naked nor dressed, } \\
\text { neither with a } \\
\text { present nor } \\
\text { without a gift. (par. } \\
\text { 32). Have you ever } \\
\text { faced such as } \\
\text { dualistic situation? } \\
\text { How did you solve } \\
\text { the problem? }\end{array}$ \\
\hline
\end{tabular}

Some of the questions, especially those questions in delving more deeply section might be quite difficult to answer since they require a deep understanding on the reading. Having the students to answer the questions in these two sections (responding to the reading and delving more deeply) were enough because the questions required the students to go deep into the text and use their logic. However, in order to get the result whether the activities with different learning styles applied correspondent with the students' personal learning style or not, the result of the additional activities in each session are the main focus.

The activities that the students had to do in each reading session were based on the learning style applied to the session. In Auditory reading session the activities were based on the auditory learning styles. The students were asked to read the first text (entitled The Blacksmith and the King - a folktale from Uganda) aloud and recorded their voice. Afterwards, they would listen to the recording while reading the text again. This session has an additional activity which is to listen to the story and catch the gist. In Visual reading session the activities were based on the visual learning styles. The students were shown a video of the story in the second text (entitled The Twelve Animals 
of the Zodiac - a folktale from China) that they were about to read. After reading the text, as the additional activity, the students asked to draw comics in groups based on their groups' interpretation. In Kinesthetic reading session the activities were based on the kinesthetic learning styles. In this session, as the additional activity, the students were asked to do a role-play based on their interpretation of the third text (entitled The Tsar's Riddles - a folktale from Russia). At the end of each reading session, the students were asked to do the questions in responding to the reading and the delving more deeply writing. Each question required a deep understanding to the text. After each session, scores were taken to see how well the students performed in the sessions. The scoring rubric is as explained in Table 2:

Table 2. The scoring rubric

\begin{tabular}{|c|c|c|c|c|c|}
\hline \multirow{2}{*}{$\begin{array}{l}\text { Responding } \\
\text { to the } \\
\text { reading }\end{array}$} & \multirow{2}{*}{$\begin{array}{c}\text { Delving } \\
\text { more deeply }\end{array}$} & \multicolumn{2}{|c|}{ Visual } & \multirow{2}{*}{$\begin{array}{c}\text { Auditory } \\
\text { Individual } \\
\text { Performance }\end{array}$} & \multirow{2}{*}{$\begin{array}{c}\text { Kinesthetic } \\
\text { Role Play }\end{array}$} \\
\hline & & Comics & Presentation & & \\
\hline $\begin{array}{l}\mathbf{9 0 - 1 0 0} \\
\text { (Excellent): } \\
\text { able to get the } \\
\text { gist and } \\
\text { understand } \\
\text { the meaning } \\
\text { of the story } \\
\text { and answer } \\
\text { both question } \\
\text { excellently } \\
\text { based on the } \\
\text { story. }\end{array}$ & $\begin{array}{l}\mathbf{9 0 - 1 0 0} \\
\text { (Excellent): } \\
\text { able to get the } \\
\text { gist and } \\
\text { understand } \\
\text { the meaning } \\
\text { of the story } \\
\text { and answer } \\
\text { both question } \\
\text { excellently } \\
\text { based on the } \\
\text { story. }\end{array}$ & $\begin{array}{l}\mathbf{9 0 - 1 0 0} \\
\text { (Excellent): } \\
\text { The storyline } \\
\text { is clearly } \\
\text { shown, an } \\
\text { accurate } \\
\text { interpretatio } \\
\text { n of the } \\
\text { story. }\end{array}$ & $\begin{array}{l}\mathbf{9 0 - 1 0 0} \\
(\text { Excellent): } \\
\text { no text, show } \\
\text { that he/she } \\
\text { knows what } \\
\text { he/she is } \\
\text { talking about, } \\
\text { fluent, } \\
\text { accurate } \\
\text { pronunciation } \\
\text {. }\end{array}$ & $\begin{array}{l}\mathbf{9 0}-\mathbf{1 0 0} \\
(\text { Excellent): } \\
\text { the student is } \\
\text { very active, } \\
\text { able to read } \\
\text { out loud in } \\
\text { correct } \\
\text { pronunciation } \\
\text { fluency in } \\
\text { reading out } \\
\text { loud the text. }\end{array}$ & $\begin{array}{l}\mathbf{9 0} \text { - 100 } \\
\text { (Excellent): } \\
\text { an accurate } \\
\text { interpretation } \\
\text { of the story, a } \\
\text { clear } \\
\text { pronunciation } \\
\text { for each } \\
\text { dialogue, } \\
\text { good acting } \\
\text { skill }\end{array}$ \\
\hline $\begin{array}{l}\mathbf{8 6}-\mathbf{8 9} \\
\text { (Very good): } \\
\text { able to get the } \\
\text { gist of the } \\
\text { story but one } \\
\text { of the } \\
\text { answers to } \\
\text { both } \\
\text { questions } \\
\text { does not } \\
\text { answer the } \\
\text { question. }\end{array}$ & $\begin{array}{l}\mathbf{8 6}-\mathbf{8 9} \\
\text { (Very good): } \\
\text { able to get the } \\
\text { gist of the } \\
\text { story but one } \\
\text { of the } \\
\text { answers to } \\
\text { both } \\
\text { questions } \\
\text { does not } \\
\text { answer the } \\
\text { question. }\end{array}$ & $\begin{array}{l}\mathbf{8 6}-\mathbf{8 9} \\
\text { (Very good): } \\
\text { the storyline } \\
\text { is shown but } \\
\text { not very } \\
\text { clearly - } \\
\text { slightly } \\
\text { confusing, } \\
\text { an accurate } \\
\text { interpretatio } \\
\text { n of the } \\
\text { story. }\end{array}$ & $\begin{array}{l}\mathbf{8 6 - 8 9} \text { (Very } \\
\text { good): no } \\
\text { text, show } \\
\text { that he/she } \\
\text { knows what } \\
\text { he/she is } \\
\text { talking about } \\
\text { with a slight } \\
\text { of mistake, } \\
\text { fluent, } \\
\text { slightly } \\
\text { inaccurate } \\
\text { pronunciation }\end{array}$ & $\begin{array}{l}\mathbf{8 6 - 8 9} \text { (Very } \\
\text { good): the } \\
\text { student shows } \\
\text { a good effort } \\
\text { in doing the } \\
\text { activity. The } \\
\text { student is able } \\
\text { to read out } \\
\text { loud well } \\
\text { with minor } \\
\text { mistakes in } \\
\text { the } \\
\text { pronunciation } \\
\text { and with } \\
\text { minor } \\
\text { stuttering. }\end{array}$ & $\begin{array}{l}\mathbf{8 6 - 8 9} \text { (Very } \\
\text { good): an } \\
\text { accurate } \\
\text { interpretation } \\
\text { of the story, } \\
\text { less clear } \\
\text { pronunciation } \\
\text { for each } \\
\text { dialogue, } \\
\text { good acting } \\
\text { skill. }\end{array}$ \\
\hline
\end{tabular}




\begin{tabular}{|c|c|c|c|c|c|}
\hline $\begin{array}{l}\mathbf{8 0 - 8 5} \\
\text { (Good): } \\
\text { struggles in } \\
\text { understandin } \\
\mathrm{g} \text { the story } \\
\text { and answers } \\
\text { well only one } \\
\text { of the } \\
\text { questions. }\end{array}$ & $\begin{array}{l}\mathbf{8 0 - 8 5} \\
\text { (Good): } \\
\text { struggles in } \\
\text { understandin } \\
\mathrm{g} \text { the story } \\
\text { and answers } \\
\text { well only one } \\
\text { of the } \\
\text { questions. }\end{array}$ & $\begin{array}{l}\mathbf{8 0}-\mathbf{8 5} \\
\text { (Good): } \\
\text { clearly } \\
\text { shows the } \\
\text { storyline, } \\
\text { slightly } \\
\text { inaccurate } \\
\text { interpretatio } \\
n \text { of the story }\end{array}$ & $\begin{array}{l}\mathbf{8 0}-\mathbf{8 5} \\
\text { (Good): no } \\
\text { text, a little } \\
\text { bit of } \\
\text { memorizing } \\
\text { with some } \\
\text { mistakes and } \\
\text { inaccurate } \\
\text { pronunciation }\end{array}$ & $\begin{array}{l}\mathbf{8 0}-\mathbf{8 5} \\
\text { (Good): the } \\
\text { student shows } \\
\text { an effort but } \\
\text { struggles with } \\
\text { the } \\
\text { pronunciation } \\
\text { and do a lot } \\
\text { of stuttering. }\end{array}$ & $\begin{array}{l}\mathbf{8 0}-\mathbf{8 5} \\
\text { (Good): } \\
\text { slightly } \\
\text { inaccurate } \\
\text { interpretation } \\
\text { of the story, } \\
\text { slightly } \\
\text { unclear } \\
\text { pronunciation } \\
\text { for each } \\
\text { dialogue, } \\
\text { average } \\
\text { acting skill. }\end{array}$ \\
\hline $\begin{array}{l}75-79 \\
\text { (Poor): } \\
\text { struggles in } \\
\text { understandin } \\
\text { g the story } \\
\text { with a little } \\
\text { effort, does } \\
\text { not answer } \\
\text { both } \\
\text { questions } \\
\text { well.vc }\end{array}$ & $\begin{array}{l}\mathbf{7 5 - 7 9} \\
\text { (Poor): } \\
\text { struggles in } \\
\text { understandin } \\
\text { g the story } \\
\text { with a little } \\
\text { effort, does } \\
\text { not answer } \\
\text { both } \\
\text { questions } \\
\text { well. }\end{array}$ & $\begin{array}{l}\mathbf{7 5 - 7 9} \\
\text { (Poor): the } \\
\text { storyline is } \\
\text { not clear - } \\
\text { rather } \\
\text { confusing, } \\
\text { slightly } \\
\text { inaccurate } \\
\text { interpretatio } \\
\text { n of the } \\
\text { story, shows } \\
\text { some efforts }\end{array}$ & $\begin{array}{l}75-79 \\
\text { (Poor): read a } \\
\text { text or clearly } \\
\text { shows that } \\
\text { he/she is } \\
\text { memorizing, } \\
\text { do no show a } \\
\text { mastery on } \\
\text { the topic, less } \\
\text { fluent, a lot of } \\
\text { inaccurate } \\
\text { pronunciation }\end{array}$ & $\begin{array}{l}\mathbf{7 5 - 7 9} \\
\text { (Poor): the } \\
\text { student shows } \\
\text { a little effort } \\
\text { and struggles } \\
\text { with the } \\
\text { pronunciation } \\
\text { and stutter. }\end{array}$ & $\begin{array}{l}\mathbf{7 5 - 7 9} \\
\text { (Poor): } \\
\text { slightly } \\
\text { inaccurate } \\
\text { interpretation } \\
\text { of the story, } \\
\text { struggles with } \\
\text { pronunciation } \\
\text {, shows some } \\
\text { effort, } \\
\text { average } \\
\text { acting skill. }\end{array}$ \\
\hline
\end{tabular}

There were two activities that the students had to do in every session with one or two additional activities based on the learning style applied to the session. The two activities that should be done in every session were the responding to the reading and the delving more deeply writing. The additional activities were: (1) drawing comics and presentation for the visual reading session, (2) individual performance in which the students have to listen to their part of story, catch the gist, and share it to their friends, and (3) role-play for the kinesthetic reading session.

\section{The result}

Based on the daily observation, the class chosen to be the respondents in this research, was likely to have the majority of the students to be in the kinesthetic learning group. Indeed, out of 40 students who took the test, 16 students $(40 \%)$ belong to the kinesthetic learning style group, 13 students $(32.5 \%)$ belong to the visual learning style group, and 11 students $(27.5 \%)$ belong to the auditory learning style group.

The first session is the auditory session. In this reading session, most students did well in answering the questions. The first session, auditory session, has three activities. First, since this session used Auditory learning style, students, therefore, were asked to read the text out loud. The students were put in groups of three to four. Each students were given the same reading and the same task - each of them got a copy of the reading and the tasks. The first reading was The Blacksmith and the King. They were asked to divide the reading among them. Each students read their part to their friends in the group. While a student was reading his or her part, the others had to read and listen at the same time. The pronunciation was ignored as it was not part of the research. Second, the students were asked to read out loud once again but this time they had to record their voice. After that, the students listened to the recording several times. In the third activity, the students had to do the tasks provided below the text. This time, while doing the tasks and answering the questions, the students listened and read the text again at the same time.

During this reading session, there were some problems occurred because many of the students were not used to reading a long text, either to read silently or to read out loud. The three problems that occurred during the process concerned with: (1) the vocabulary: some students stopped 
to ask about the meaning of certain words despite the glossary provided. They were told to get the meaning of the word by looking at the context instead of the meaning of each word; (2) the recording session: some students stopped reading because he or she got confused on how to pronounce certain words even though they were told that the pronunciation would be ignored. They refused to continue before they knew how to pronounce it well which affected the voice recording process; (3) the tasks: some students could not proceed with the tasks because they did not understand the story despite having the recording to listen to and a text to read from. After the third activity, most of the students managed to finish the task. However, some of the weaker students still struggled, therefore, an additional auditory activity was added: a story telling done by students who understood the story to those who did not. It worked quite well.

The story used in this session was about a King who gave an impossible task to a blacksmith: to forge a real man of iron who can walk and talk, has blood in his veins, knowledge in his head and feelings in his heart. Out of his confusion, the blacksmith got ideas from his peers to make the King understand that not everything can be done by human (to make an iron man who can walk and talk, has blood in his veins, knowledge in his head and feelings in his heart). In general, most of the students who belong to auditory learning group did well in this session. For example, one student who was able to get the main messages from the story: (1) not everything can be done by human, (2) tells people not to be greedy and ask something impossible, and (3) it is good for children to teach them to be honest about something they cannot do (referring to the Blacksmith who did not dare to be honest to the King about the impossibility for him to forge the man). This student's answer shows his understanding on the reading. He answered well and actually got the message from the story.

The main focus is on the additional activity in which the students have to listen to their part of the story, catch the gist, and share it to their groups. In the end, each group will get the complete story. The students, then, were asked to tell the story and recorded it with their smart phones. The recording was submitted and graded based on their understanding to the story. Some students told the story exactly as it was and some others told the story based on what they could catch during the telling stories activity.

Table 3. The scores of auditory students compared to the other learning style activities

\begin{tabular}{|c|l|l|c|c|c|c|}
\hline \multirow{2}{*}{ NO } & & \multicolumn{2}{|c|}{ V } & A & K \\
\cline { 3 - 7 } & & 3 & 4 & 3 & 3 \\
\hline 5 & Student Ca & 80 & 84 & $\mathbf{8 6}$ & 84 \\
\hline 8 & Student Da & 76 & 80 & $\mathbf{8 8}$ & 84 \\
\hline 11 & Student Ha & 83 & 84 & $\mathbf{9 1}$ & 89 \\
\hline 12 & Student He & 82 & 83 & $\mathbf{9 1}$ & 86 \\
\hline 13 & Student I & 79 & 83 & $\mathbf{8 9}$ & 85 \\
\hline 14 & Student Je & 86 & 85 & $\mathbf{9 3}$ & 84 \\
\hline 16 & Student Jess & 85 & 84 & $\mathbf{8 9}$ & 88 \\
\hline 18 & Student Jo & 83 & 84 & $\mathbf{8 7}$ & 85 \\
\hline 24 & Student Me & 86 & 86 & $\mathbf{9 0}$ & 84 \\
\hline 38 & Student W & 85 & 83 & $\mathbf{8 9}$ & 85 \\
\hline \multirow{5}{*}{ V = visual } & 40 & Student Y & 88 & 91 & $\mathbf{9 6}$ & 90 \\
\hline
\end{tabular}

$\mathrm{A}=$

$\mathrm{K}=$ Kinesthetic 
The scores for auditory students in this reading section shows quite a big difference compared to their scores in the two other learning sessions. There are a couple of students whose scores in every section are quite similar. These students' level of English is quite high compared to the rest of the class. The result shows that all of the auditory students scored their highest in this reading session.

In the second session, a longer text was given to the students. The reading is a Chinese folktale's The Twelve Animals of the Zodiac. In this session the Visual learning style is used. The students did their task individually in this session. The students were told not to read the text before they were allowed to. Before reading the text, the students were shown a simple animation video about The Twelve Animals of the Zodiac. Most of the students are of Chinese descend, so they were familiar with the story. There are many versions of the story, but the basic of the story is the same. After watching the animation video, the students were asked to read the story individually. Since this was their second session done right after the first one, a couple of students had started to get used to it. Helped by the video and the student's prior knowledge on the twelve zodiac story, the reading session happened in a better phase. There were words that they did not know, but they looked them up in the dictionary. Only a few students struggled in this session. There were some students who still asked about certain things about the story, but mostly about the vocabulary, which they still could not relate the meaning of the word with the context in the story, that they looked up in the dictionary.

In order to make the result to be more valid, activities based on visual learning preferences are needed to see if the students in visual learning group actually perform their best in this reading session. Therefore, apart from answering the questions that follow the short stories, the students were given additional activities based on the learning styles applied. In the first reading session in which visual learning style was applied, individually, the students were asked to draw a comic based on the story. This activity is a collaboration with the Art Class. However, the scores taken for the English class ignored the students' ability to draw. The scores were taken based on the storyline and the accuracy of intepreting the story. Afterwards, also individually, the students had to display and present their comics to the class.

The result shows that among the thirteen students whose personal learning style is visual, almost all of them scored highly in this reading session except three students: (1) Student C and Student $\mathrm{P}$ who scored higher in auditory learning session, (2) Student D who scored higher in kinesthetic learning style. More on this matter will be explained later in 4.5 special cases. As it was previously mention in the methodology section, the students were shown a video based on the short story used in this session. The video, even though it was of a different version than the text, helped the students to get ideas and overview on interpreting the story. Many of the students came up with their own version of the story without going out too far from the original story.

The individual presentation went well as well. The students, in turn, displayed their comics around the class and present their interpretation of the story, the reason why they came up with their version of the story, the purpose of their interpretation of the story.

Table 4. The scores of visual students compared to the other learning style activities

\begin{tabular}{|c|l|c|c|c|c|}
\hline \multirow{2}{*}{ NO } & & \multicolumn{2}{|c|}{ V } & A & K \\
\cline { 3 - 6 } & & 3 & 4 & 3 & 3 \\
\hline 6 & Student Ce & $\mathbf{8 8}$ & $\mathbf{8 8}$ & 84 & 85 \\
\hline 7 & Student C & $\mathbf{8 5}$ & $\mathbf{8 8}$ & 89 & 87 \\
\hline 9 & Student D & $\mathbf{8 5}$ & $\mathbf{8 5}$ & 84 & 88 \\
\hline 15 & Student Jen & $\mathbf{8 8}$ & $\mathbf{9 4}$ & 85 & 84 \\
\hline 19 & Student Jon & $\mathbf{8 7}$ & $\mathbf{8 8}$ & 85 & 84 \\
\hline 23 & Student L & $\mathbf{8 9}$ & $\mathbf{8 5}$ & 79 & 80 \\
\hline 25 & Student MN & $\mathbf{8 8}$ & $\mathbf{9 0}$ & 84 & 85 \\
\hline 28 & Student N & $\mathbf{8 8}$ & $\mathbf{8 8}$ & 84 & 85 \\
\hline 30 & Student Ni & $\mathbf{8 7}$ & $\mathbf{9 0}$ & 78 & 83 \\
\hline
\end{tabular}




\begin{tabular}{|l|l|l|l|l|l|}
\cline { 2 - 6 } 31 & Student $\mathbf{P}$ & $\mathbf{8 5}$ & $\mathbf{8 4}$ & 92 & 86 \\
\hline 32 & Student Pr & $\mathbf{8 8}$ & $\mathbf{9 2}$ & 85 & 84 \\
\hline 36 & Student S & $\mathbf{8 8}$ & $\mathbf{8 3}$ & 84 & 85 \\
\hline 37 & Student V & $\mathbf{8 8}$ & $\mathbf{9 0}$ & 85 & 83 \\
\hline
\end{tabular}

$$
\mathrm{V}=\text { visual } \quad \mathrm{A}=\text { Auditory } \quad \mathrm{K}=\text { Kinesthetic }
$$

The table above shows the comparison of scores of students with visual personal learning style in visual learning session and other learning sessions (auditory and kinesthetic). Three students resulted higher in learning sessions different than their personal learning style, but most of the students in visual learning style group scored their best in this session.

In the third session, a text entitled The Tsar's Riddles was used as the reading material. This text was the longest of the three texts used in the research. The vocabulary was quite difficult even though there was the glossary page after the last page of the text. Everyone had not read or heard about the story as Russian's folklores are not familiar to Indonesian's readers. The time set for this session was three meetings or 135 minutes. However, in fact, the third session took up longer than planned because the students had to do a role play for the additional task. They needed longer time to prepare themselves and do the role play. The third session took six meetings at the end or 270 minutes.

In this session, students did not just read but also acted the story out. The third session used the kinesthetic style of learning which means the students learned by doing something. They had to do a role play. With six students each, there were eight groups formed for the role play. In the previous two sessions of the other two learning styles, the students were asked to do the writing tasks right after they finished reading the text. However, in the third session, the students had to do the role play before they did the writing tasks.

The only problem occurred during this session was that the preparation of the role play took quite a long time because the students did not want to do the role play impromptu. The idea was to get the students read the text, then put them in groups. Each group was asked to create a role play on the text based on their groups' interpretation. However, the text was not easy to understand for some students. The vocabulary was quite difficult and the text was quite long. It ended up with two meetings of reading and understanding the text. It was decided to group some strong students with weaker students to help them with the understanding. Among the sixteen student who belong to kinesthetic learning style group, there is one student (a boy) who scored the highest on different learning session - in this case auditory learning session. More about this student will be explained further in the next part.

The third story was about two brothers: one is rich and one is poor. Both brothers had a horse each: the rich brother's was a gelding and the poor brother's was a mare. One night the poor man's mare bore a foal and it rolled under the rich brother's cart resulted in the rich brother claimed the foal to be his. To settle the matter, both brothers went to the Tsar. The Tsar gave them riddles to solve. At the end, the poor brother's daughter wisely and smartly solved all the Tsar riddles and the poor brother got his foal back. One example of a good answer was this one girl; although her answer looks incomplete because she 'only answered' the first question, her answer for the first question has already covered the second question. She said that the little girl respected others especially her father. She wanted to help her father fight for what was right and get what belonged to him. Her answer to the questions showed her understanding to the text.

Since the additional activity is role play, students were divided into five groups of eight. Each group had to interpret the text and made it into a role play. The role play was done in groups, but the students were marked on their individual performance: their dialogue and the acting. Through their acting, it could be seen how much the students understand their roles. The interpretation of the text was done in groups so it was not analyzed here; only the students' individual performance (acting) is graded. The result shows that the number of students belong to the good and very good categories are equal. This occurrence might be because acting needs both talent and confidence. 
Some kinesthetic students might be less confident to act in front of the class than some other students. However, the number of students who were successfully got into the excellent category is quite big. Half of the kinesthetic students performed very well in this reading session.

Table 5. The scores of kinesthetic students compared to the other learning style activities

\begin{tabular}{|c|l|c|c|c|c|}
\hline \multirow{2}{*}{ NO } & & \multicolumn{2}{|c|}{ NAME } & A & K \\
\cline { 3 - 6 } & & 3 & 4 & 3 & 3 \\
\hline 1 & Student A & 85 & 85 & 83 & 86 \\
\hline 2 & Student AM & 84 & 85 & 84 & 87 \\
\hline 3 & Student All & 75 & 82 & 84 & 86 \\
\hline 4 & Student An & 77 & 85 & 85 & 88 \\
\hline 10 & Student E & 80 & 90 & 83 & 84 \\
\hline 17 & Student JA & 83 & 83 & 85 & 89 \\
\hline 20 & Student JG & 89 & 89 & 88 & 90 \\
\hline 21 & Student Ke & 89 & 90 & 91 & 93 \\
\hline 22 & Student Kez & 85 & 90 & 85 & 88 \\
\hline 26 & Student M & 84 & 84 & 88 & 86 \\
\hline 27 & Student MT & 86 & 88 & 84 & 87 \\
\hline 29 & Student NC & 84 & 83 & 87 & 88 \\
\hline 33 & Student Ra & 87 & 86 & 85 & 90 \\
\hline 34 & Student Ry & 88 & 88 & 85 & 93 \\
\hline 35 & Student S & 76 & 75 & 83 & 89 \\
\hline 39 & Student Yo & 85 & 88 & 84 & 89 \\
\hline
\end{tabular}

$$
\mathrm{V}=\text { visual } \quad \mathrm{A}=\text { Auditory } \quad \mathrm{K}=\text { Kinesthetic }
$$

Among thirteen students who belong to the kinesthetic group, most of them performed well in this reading session. As it was mentioned before, kinesthetic students tend to move around. That is why most of them enjoyed doing the acting. However, there was one student (Student M) who, despite having kinesthetic learning style, did not score well in this reading session.

\section{Poor performance}

There were students who performed excellently in the sessions and students who performed well. However, there were also students who performed poorly in the sessions - might not be all of the sessions but only one or two sessions that do not match their learning interest. In each session, there were always students who did not do well for some reasons: (1) Visual reading session - the question in this session should be quite easy to answer and the story for this session is one of the popular stories among the students. Yet, there are students who performed poorly. One of these students was a girl. She had a good idea regarding the story, but she did not answer the question given in the tasks. (2) Auditory reading session - the reading text and the questions in this reading session were rather simple compared to the other two reading sessions since this session was the first out of the three reading sessions. However, there were students who did poorly. One of these students was a boy. He was not good at English and did not show or put any efforts in improving his English skills. Perhaps it was one of the reasons why he did not perform well in this session. (3) Kinesthetic reading session - this reading session was the last of the three session. It was expected that the students would have started to get used to reading a long text. However, there were still some students who did poorly in the session. There was this one student, a boy, who did not seem to have the will to answer the questions in the comprehension task. He only gave one or two words as his answers. 
When asked, he said that he did not like the additional activity in this session, which was a role-play. Therefore, he had a low motivation in joining the activities.

\section{Special cases}

Although the result of the research was pretty much as expected, there are special cases. Only the other $10 \%$ (4 students) resulted differently than their individual learning tested at the beginning of the research. There are many possibilities on how the four students resulted differently than their original learning styles. There are students who performed excellently in the sessions and students who performed well. However, there are also students who performed poorly in the sessions -not in all sessions but only one or two sessions that do not match their learning interest.

There are also special cases: the cases where the students scored their best score in reading session that did not match their personal learning style. There are a total of five special cases that occurred during the research: (1) The first problem, among the thirteen students belonging to visual learning style group, there were two female students who were supposed to be in the visual group but scored the highest on the first session (auditory style learning). (2) The second problem, among the sixteen students in the kinesthetic learning group, there is one student, a male, who scored the highest in auditory learning session. This result, although unexpected, is not that surprising considering his everyday performance in the class. This student, unlike the other students with kinesthetic learning style, did not show any enthusiasm during the role play session. (3) And the third and last problem is about one male student. The problem is similar to the other previous two, only this time the student belongs to the visual learning group but scored the highest on the kinesthetic learning session Based on his daily performance in class, this student moves a lot during the lesson. It was quite surprising to see that he got into the visual group rather than the kinesthetic group. However, the final result from the three sessions shows that he belongs more to the kinesthetic group - not the visual group.

It is possible that during the activities, their secondary learning styles became more dominant than their primary learning styles. In his journal, Fleming (1992) did mention about people who had more than one types of learning style with one particular learning style being the dominant. However, in this research, only one personal learning style for each student was recognized. One of the reasons was because the tool used for generating the students' answers to the personal learning style questionnaire could only recognize one type of learning style for each student - their dominant learning style. Therefore, if a student happened to have a dominant and a secondary learning styles, the program could only recognize the dominant one. Another possibility is that when the students answer the questionnaire, they might do it based on their ideal thought instead of what they will do in real life. For example, when they were asked what they would do if they wanted to operate a new device, the students might answer the option that looked more ideal to them instead of what they would actually do in reality.

\section{Conclusion}

In general, applying different learning styles in doing reading with the students shows a good result both for the weak students and the good students. Some of the weaker students in class showed a satisfying result even though they might still need to work harder, and the good students in the class, even though it was not much, also showed an improvement in their way of understanding a reading text. Most of the students did well in the learning sessions that match their personal learning style. There are only a few students who had special cases. There are also possibilities on why there are students who still struggled: firstly, these students are weak in learning a new language especially English. Secondly, they might not put enough efforts in doing the activities and the evaluation questions in each reading session. Probably using a test that can identify students' secondary or even their third learning styles will show more about the occurrence on why there were students who were supposed to be in certain learning style group but scored their highest in different learning style reading session. It might also show someone's personal learning style's degree of dominance. 


\section{Bibliography}

Cohen, A. D. (2010). Focus on the Language Learner: Styles, Strategies and Motivation. In N. Schmitt, An Introduction to Applied Linguistics 2nd Edition (pp. 161-178). London: Routledge.

Fleming, N. D., \& Mills, C. (1992). Not Another Inventory, Rather a Catalyst for Reflection. To Improve the Academy, 137.

Fleming, N., \& Baume, D. (2006, November 4). Learning Styles Again: VARKing up the right tree! Educational Developments, 4-7.

Kuntjara, E., \& Rini, J. E. (2012). Readings for Peace Education Through Folklore. Yogyakarta : GRAHA ILMU.

Puchta, H. (2017). About Herbert Puchta. Retrieved from Herbert Puchta: http://www.herbertpuchta.com/about/

Puchta, H., \& Stranks, J. (2011). English In Mind Second Edition Book 3. Singapore: Cambridge University Press.

Pearson, A. (2017). The Top-Down Reading Model Theory. Retrieved from Our Everyday Life: http://oureverydaylife.com/topdown-reading-model-theory-13028.html

Snow, C. E. (2002). Reading for understanding : toward a research and development program in . Santa Monica: RAND.

Spratt, M., Pulverness, A., \& Williams, M. (2012). The TKT Teaching Knowledge Test Course Book Modules 1,2 and 3. Singapore: Cambridge University Press. 